\title{
XLIV. On aërostation
}

\section{Richard Lovell Edgeworth Esq. F.R.S.}

To cite this article: Richard Lovell Edgeworth Esq. F.R.S. (1816) XLIV. On aërostation, Philosophical Magazine Series 1, 47:215, 185-187, DOI: 10.1080/14786441608638832

To link to this article: http://dx.doi.org/10.1080/14786441608638832

$$
\text { 曲 Published online: } 27 \text { Jul } 2009 .
$$

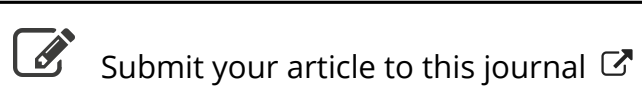

\footnotetext{
Џ Article views: 2
}

Q View related articles $₫$ 
Recollecting the degrees of cold which are destructive to different vegetables growing in this kingdom, that even turneps on the ground in winter are injured by $24^{\circ}$ and totally destroyed by $30^{\circ}$ below the freezing point ; we may naturally conclude that great devastation must have been conmitted by the late severe weather : but the destruction would have been unparalleled in this kingdom, had not the ground been previously corered by snow, especially as the sun rose with spleadour on the morning of the $9 \mathrm{th}$ ult., thus greatly augmenting the danger to the living principle. Therefore, when we reflect upon these circumstances, what a powerful source of gratitude they ought to prove in our minds, to that great and beneficent Being, who has spread such a protecting mantle over the fertile fields of this highly cultivated country!

Wisbech, March 8, 1816.

I remain, sir, Yours, \&c.

XliV. On Ä̈rostation. By Richard Lovell Edgewonth,

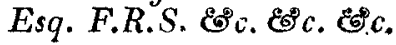

\section{To Mr. Tillnch.}

SIR, $-T_{\text {Here is something apparently selish and ungracious }}$ in claiming inventions that are published by others. But in philosophy, as well as in law, a fatal error is often committed by laches,-or, in plain English, by leaving unclaimed, for a length of time, a right that belongs to us.

The ingenious Sir George Cayley has frequently proposed to impel flying bodies, by letting them descend obliquely through the air, and forcing them in a contrary obliquity against the air by impelling them upwards. He refers to Mr. Evans's paper in your Magazine for November last. Now, sir, I did actually apply this invention to a small fire-balloon at my own house in the year 1786, which confirmed me in the opinion of the practicability of this invention. But as there were a great number of thatched houses in my neighbourhood, I desisted from making further trials.

In 1802 I became acquainted with M. Montgolfier at Paris, when two of my friends who were with me, asked M. Montgolfier whether any practicable means of directing balloons had ever been communicated to him. He replied, "Never, but in a letter from a gentleman in Ireland." One of my friends immediately inquired, whether that letter had been communicated to him in the year 1782, by the Marquis de la Poÿpe, of Bourg en 
Bresse. He said that it was. "Then," said my friend, "that letter was written by Mr. Edgeworth, for I saw it when it was dispatched."

Montgolfier was extremely pleased; took the trouble of explaining to me many of his ingenious contrivances, particularly his belier hydraulique.

I cannot omit to mention an instance of M. Montgolfer's candour and generosity. After having taken considerable pains to obviate objections which had been made to his parachute, I communicated to him the means of rendering the descent of the parachute perfectly safe and equable.

When we were going away, we passed through the magnifcent staircase of the Conservatoire des Arts et Metiers, Rue St. Martin. "There," said he, pointing to the dome, "is an instance of national gratitude; you see the remains of my original balloon suspended from the roof, and my parachute annexed to it. I will have my parachute taken down, and yours substituted in its place."

These, however, are relations resting merely on assertion,but in the Transactions of the Royal Irish Academy, vol. vi. page 101, there is in an Essay of mine the following note:

"A balloon may be carried forward with certainty and celerity in any direction where there is no perceptible wind, if it is alternately lowered and elevated by altering from time to time its specific gravity, which may be done by various means, without losing much hydrogen gas; and if it be furnished with fins or small sails, and be set to a proper angle, with its line of ascent and descent, their vertical pressure against the air will impel the balloon forward."

"Swift manouvres his Laputa in this manner:

"I tried this invention on a small balloon in the house of the late ingenious Dr. Usher, (Professor of Astronomy in the University of Dublin), the friend of science, and of those who wished to improve it."

I do not mean to insinuate in the most remote manner, that Sir George Cayley or Mr. Evans knew any thing of my invention; probably they never heard my name; and far from wishing to derogate from their merit, $I$ shall with pleasure contribute to a subscription for carrying on any practicable plan for the advancement of aërostation. Earnestly hoping that it may be applied to better purposes than those to whieh it has been hitherta unworthily confined,

$$
\begin{aligned}
& \text { I am, sir, } \\
& \begin{array}{c}
\text { Your obedient servant, } \\
\text { Richo Lovell Edgewthistown, Ireland, } \\
\text { Niarch 6, 1816. }
\end{array}
\end{aligned}
$$




\section{Report of the Lalours of the French Arehitects at Rome. 187}

P. S.-One of the most powerful means of retarding the progress of aërostation has been ridicule. In the Essay to which 1 have alluded there is the following passage :

"The disposition to ridicule every scientific project as absurd, until it has been absolutely brought to perfection, has been the common topic of complaint amongst men of inventive renius; and it is curious to observe, that poets, who suffer so much themselves by the taunts of men of the world, and by the apathy of the vulgar, should in their turn revenge themselves upori men of science, and treat their speculations with disdain. Ben Jonson has attempted this, in one of his masques, with a degree of himonr which is not alwars the portion of those who throw ridicule on science. Merefool, the clown of the piece, consults an adept, who promises to instruct him in all occult secrets. and to show him apparitions of all the learned men of the ancients; but every man who is called for happens to be busy, from $\mathrm{Py}$ thagoras, "who has rashly run himself upon an employment of keeping asses from a field of beans,' to Archimedes, who is meditating the invention of

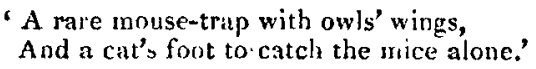

"Not only the same taste for ridicule, but the same ideas, we find repeated, with a slight alteration, at different æras. Aristophanes and Lucian amengst the ancients; and Butler, Swift, and Voltaire, the three modern masters of ridicule, have in various shapes the same ideas, and are alike disposed to confound the ingenious and the extravagant. The best way of parrying the stroke of ridicule is to receive it with good humour; Laugh with those who laugh, and persevere with those who labour, should be the motto of men who possess the powers of invention.

"The late Dr. Johnson, who in his Rasselas ridiculed the idea of the art of flying, lived long enough to see the ascent of the first air-balloon."

XLV. Report made by Messrs. Hrurtier, Percier, and $\mathrm{DU}$ Fourny, to the Class of Fine Arts of the French Institule, of the Labours of the Firench Archilects at Rome during the Years 1812 and $1813^{*}$.

G

Grantemen,-You will recollect that the labours prescriber by your regulations to the pupils who are architectural pensioners

* Magasin Encyclopédique, Nov. 1815. 